\title{
Grass utilization and grazing distribution within intensively managed fields in Central Alberta
}

\author{
BARRY D. IRVING, PAT L. RUTLEDGE, ARTHUR W. BAILEY, M. ANNE NAETH, AND \\ DAVID S. CHANASYK
}

\begin{abstract}
Authors are technologist, Department of Agricultural, Food and Nutritional Science, University of Alberta, Edmonton, Alberta, Canada T6G 2P5; ranch manager, Rutledge Ranching. Box 61, Monitor, Alberta, Canada T0C 240; professor, Deparment of Agricultural, Food and Nutritional Science, University of Alberta, Edmonton, Alberta, Canada T6G 2PS; assistant professor and professor, Department of Renewable Resources, University of Alberta, Edmonton, Alberta T6G $2 \mathrm{Hl}$
\end{abstract}

\begin{abstract}
Grazing distribution and grass utilization was evaluated in intensively managed fields in the southern Aspen Parkland near Kirriemuir, Alberta. Three fields, 130 ha in size (with dimensions $.4 \times 3.2 \mathrm{~km}$ ) were grazed by $1,000 \mathrm{cow} /$ calf pairs for 5 days each. Stock water was accessible only from one end of each field. Grazing distribution was evaluated by monitoring grass utilization daily during grazing and after grazing at 0.1, 0.8, 1.6, 2.4, and $3.1 \mathrm{~km}$ from water. Final utilization did not differ within fields, except for a decline at the maximum distance from water $(3.1 \mathrm{~km})$. Temporal utilization patterns existed and could best be described as a wave, with defoliation beginning near the water source on day 1 of grazing and proceeding outward from water until the ends of the fields were grazed on day 5. Final utilization was uniform; selective grazing of areas close to water was not removed by intensive management, but was masked by a rapid rate of defoliation.
\end{abstract}

Key Words: Alberta, stock density, short duration grazing, grazing distribution

Slope length and inclination, distance from water, and the presence of brush have been identified as factors affecting livestock distribution (Mueggler 1965, Cook 1966, Roath and Krueger 1982, Gillen et al. 1984). It is difficult to separate the factors and evaluate them individually (Cook 1966). Gillen et al. (1984) found cattle preferred areas within $200 \mathrm{~m}$ of water and avoided areas farther than $600 \mathrm{~m}$ away from water. A change from continuous grazing to deferred-rotational grazing did not appreciably change the grazing pattern. Roath and Krueger (1982) speculated that when other factors influencing livestock distribution were not limiting, distance from water ultimately controlled the outer limits of vegetation utilization. They found utilization approached 0 at distances of about $1,900 \mathrm{~m}$ from water on relatively level

Research was funded by Alberta Department of Advanced Education and NOVA Corporation of Alberia.

Manuscript accepted 11 Nov. 1994. rangeland. Recently, the use of short duration grazing (SDG) has become popular as a method to distribute grazing pressure evenly. Traditional theory proposes that increased stock density is associated with more uniform utilization in intensively managed grazing systems (Kothmann 1980). Recent studies indicate that increased stock density alone does not necessarily lead to more uniform grazing distribution (Walker et al. 1989, Kirby et al. 1986). In some cases increased stock density may even be assaciated with an increase in selective grazing (Walker et al. 1989). It has been suggested that reduced pasture size and shorter distances to water that usually accompany increases in stock density are responsible for improvements in grazing distribution (Hart et al. 1993).

The purpose of this study was to determine if grazing distribution was uniform throughout intensively managed fields. Temporal utilization patterns in relation to distance from water were also examined. Temporal utilization pattern refers to changes in utilization that occur with time during the grazing period. The central hypothesis was that grazing distribution would be uniform in intensively managed fields. A secondary hypothesis was that temporal patterns of grazing would exist, illustrating livestock selectivity.

\section{Study Site}

The study site was located in the Neutral Hills, north of Kirriemuir, Alberta at $52^{\circ} 15^{\prime \prime} \mathrm{N}, 110^{\circ} 15^{\prime \prime} \mathrm{W}(400 \mathrm{~km}$ southeast of Edmonton). The climate of the study site is continental, characterized by long warm summer and bright, cold winter days (Wyatt and Newman 1938). Mean precipitation (20 year average) was $340 \mathrm{~mm}, 70 \%$ as rain during the growing season (MaySeptember) and $30 \%$ as snow during the dormant season (October-April) (Environment Canada 1982).

The Neutral Hills are located on the boundary between the Mixed Prairie and Aspen Parkland vegetation associations. Vegetation in the Neutral Hills consists of Festuca-Stipa grasslands (Looman 1981, Coupland 1961) on south facing slopes and flat areas interspersed with aspen groves on north facing slopes. Festuca-Stipa grasslands are dominated by Festuca hallii (Vasey) 


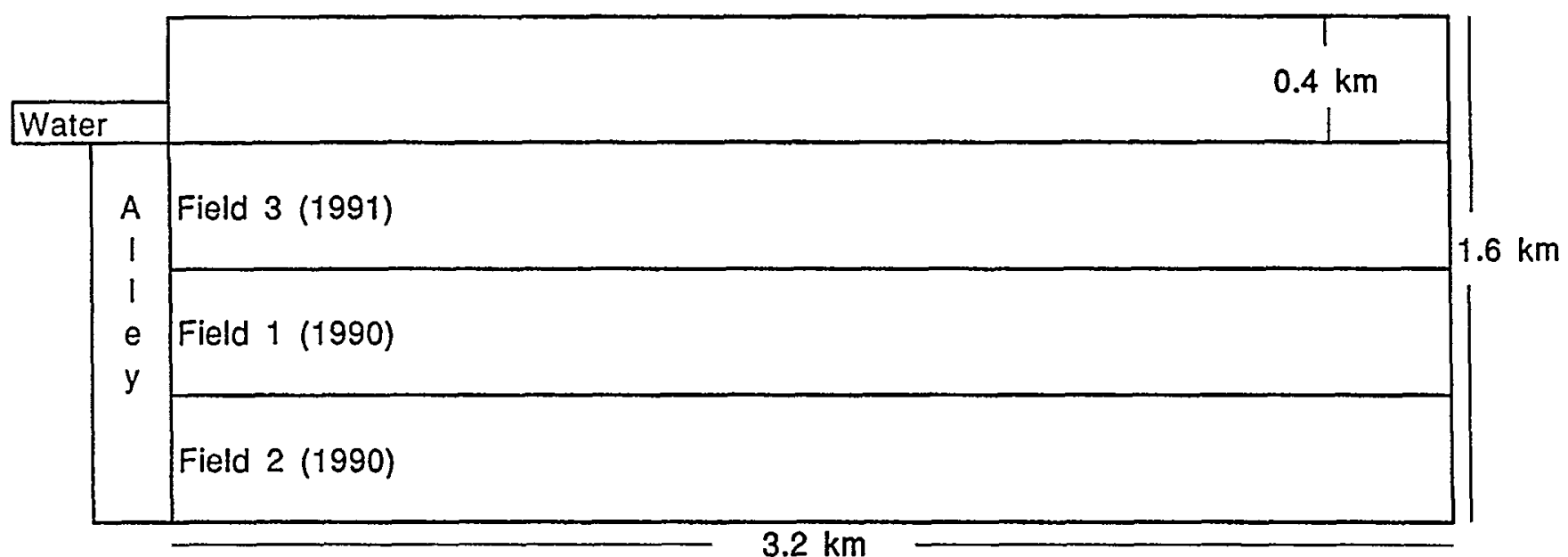

Fi g. 1. Field Layout.

Piper (Pavlick and Looman 1984) (plains rough fescue) on ungrazed sites, with Stipa curtiseta (A.S. Hitchc.) Barkworth (western porcupine grass) as a co-dominant on grazed areas. Herbage production in the study area was dominated by grasses, which contributed about $85 \%$ of the current annual growth, the remaining $15 \%$ was made up of perennial forbs (Irving 1992). Major perennial forbs were Thermopsis rhombifolia (Nutt.) Richards (buffalo bean), Cerastium arvense L. (chickweed), Anemone patens L. (crocus), and Artemisia frigida Willd. (pasture sage).

\section{Methods}

\section{Site Selection}

The study site was located on a private ranch (Rutledge Ranching) that consisted of about 13.000 ha of deeded and lease land. Continuous (season-long) grazing was the main grazing system employed on the ranch prior to 1988. In 1988, grazing management on the ranch was intensified, and an extensive fencing and stock water development program (wells) was initiated. At the end of 1989, most of the ranch had been cross fenced into 130 ha fields, each with a supplied water source. Livestock management consisted of sequentially moving a herd of about 1,000 cow/calf pairs through a series of fields (5 days stay in each field). This management yielded a stocking rate of $1.3 \mathrm{AUM} / \mathrm{ha}$ and a stocking density of $7.7 \mathrm{AU} / \mathrm{ha}$. Usually, fields were only grazed once per year.

An anomaly of management occurred in an isolated area of the ranch. A bank of hills (rising about $100 \mathrm{~m}$ above the rest of the ranch) occurred on the northern boundary of the ranch. The only source of stock water was a cluster of 3 shallow wells, located in a natural saddle in the hills. To maintain field sizes similar to those of the rest of the ranch the area serviced by the wells $(1.6 \times$ $3.2 \mathrm{~km}$ ) was fenced into four 130-ha fields, each $0.4 \times 3.2 \mathrm{~km}$ (Fig. 1). Paddocks not directly attached to the water source were accessed by cattle via an alleyway.

\section{Data Collection and Analysis}

Two fields were studied in 1990 and 1 field was studied in 1991. Standing crop of grass was sampled at $0.1,0.8,1.6,2.4$. and $3.1 \mathrm{~km}$ from the water source, or from the alleyway leading to the water source. Standing crop was estimated before and after the grazing period by hand clipping to about $1 \mathrm{~cm}, 4$ randomly located quadrats $(0.5 \times 0.5 \mathrm{~m})$ at each distance. Each sample site was individually identified with a numbered stake. All samples were oven dried for 48 hours $\left(70^{\circ} \mathrm{C}\right)$ and weighed. Utilization was calculated as the percent difference between standing crop before and after grazing.

Temporal (within grazing period) utilization patterns were estimated visually. On each day of the grazing period, ocular estimates of grass utilization were made at the same sampling sites used for clipped utilization estimates. Utilization was visually estimated as $0,1-15 \%$, and thereafter in $10 \%$ classes (16-25, 26-35, etc.).

Means and standard errors of standing crop before grazing, final clipped utilization, and temporal visual utilization were calculated. Standard errors are indicative of between field variation.

\section{Results}

Standing crop of grass prior to grazing and percent utilization after completion of grazing are shown in Table 1. Standing crop among distances within fields varied, but not significantly. Clipped utilization was uniform within fields to distances of 2.4 $\mathrm{km}$, but decreased at a distance of $3.1 \mathrm{~km}$. Visual utilization estimates followed similar patterns as clipped utilization but were always less, especially at higher levels of utilization.

Although there was no difference in final utilization, except at the farthest ends of the fields, there were temporal utilization patterns (Fig. 2). Areas closer to water were utilized early in the grazing period (day 1 and 2), while areas farther than $1.6 \mathrm{~km}$ away from water were grazed in the latter half of the grazing 


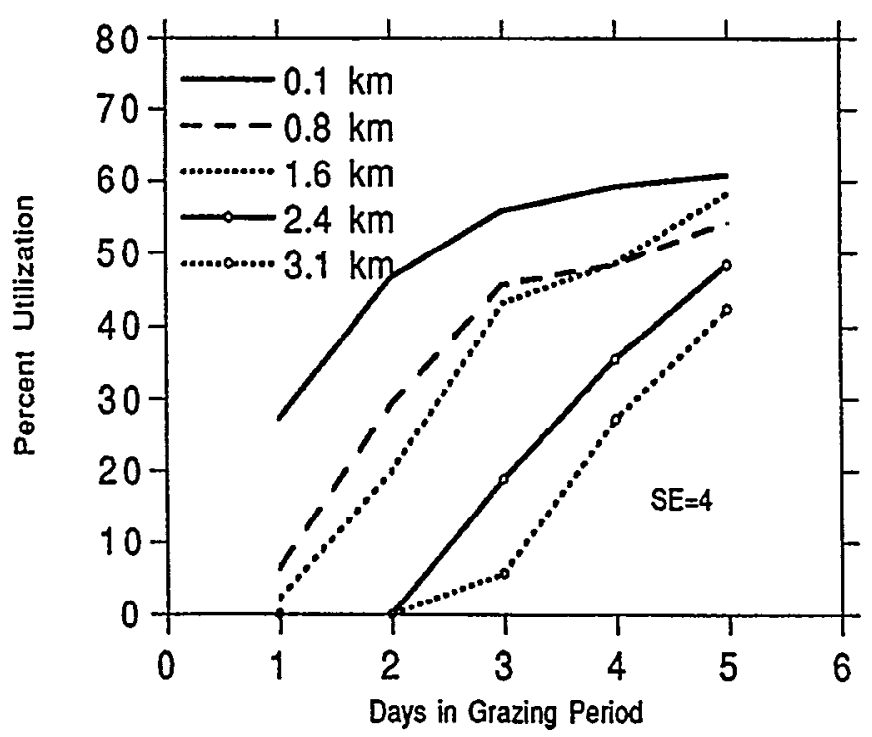

Fig. 2. Utilization ( $\%$ visually estimated) by time and distance to water. Lines are averages of 3 fields.

period (days 3,4 , and 5 ). Areas further away from water than 1.6 $\mathrm{km}$ were not grazed until areas closer than $1.6 \mathrm{~km}$ were approaching $40-50 \%$ utilization.

\section{Discussion}

If the fields in this study had been examined for utilization patterns only after the grazing period was complete, the conclusion would have been that utilization was relatively uniform, except in the far ends of the fields. However, when temporal grazing patterns were examined, the conclusion was quite different. Temporal grazing patterns can best be described as a wave of defoliation, starting closest to water and proceeding outward from it. As areas closer to water became depleted of forage, livestock ranged farther into the field. The wave of defoliation proceeded through the field until such time as utilization was uniform, when the livestock were moved to the next field. High levels of utilization close to the water source had to exist before utilization was achieved farther from the water source. Selectivity for areas close to water was not removed by high stock densities, but was masked by the speed at which the defoliation wave progressed. If fields had been large enough and regrowth rapid enough, cattle might have begun grazing regrowth near water before or instead of grazing the far ends of each field, or it might have been necessary to remove cattle before they grazed to the far end.

Temporal grazing patterns may be of importance where intensive management is used in an attempt to distribute grazing evenly across favored and avoided communities. Kirby et al. (1986) found intensive management did not result in more uniform grazing of 5 plant communities. Intensive management may actually increase selective grazing behavior (Walker et al. 1989). Traditional theory has held that increased stock density is associated with more uniform utilization in intensive management systems. It is possible that intensive systems simply mask grazing behaviors (such as selectivity for areas close to stock water) that are evident under less intensive systems. In this study, what appeared to be uniform grazing after a 5 day grazing period was
Table 1. Standing crop ( $\mathrm{kg} / \mathrm{ha})$ and utilization $(\%)$ by distance within the fields.

\begin{tabular}{lccc}
\hline \hline \multirow{2}{*}{ Distance } & $\begin{array}{c}\text { Before Grazing } \\
\text { Standing Crop }\end{array}$ & \multicolumn{2}{c}{ Final Utilization } \\
\cline { 3 - 4 } $\mathrm{km}$ & $(\mathrm{kg} / \mathrm{ha})$ & $(c)$ & $(\%)$ \\
0.1 & 600 & 67 & 60 \\
0.8 & 860 & 77 & 50 \\
1.6 & 800 & 78 & 60 \\
2.4 & 900 & 72 & 50 \\
3.1 & 730 & 50 & 40 \\
& & & \\
SE & 70 & 5 & 5 \\
\hline
\end{tabular}

actually the culmination of a wave of defoliation that ended on the fifth day. Hart et al. 1993 has postulated that improvements in grazing distribution that are associated with intensive management are usually a result of water development and smaller fields and are not necessarily caused by increases in stock density. The temporal grazing patterns documented in this study would seem to support this hypothesis.

The peculiar shape $(0.4 \times 3.2 \mathrm{~km})$ of the fields examined in this study was a result of limitations of economically available stock water. The finding of temporal grazing patterns is of interest from a research point of view. However, at the end of the 5 day grazing period utilization was fairly uniform, accomplishing a primary management goal. If final herbaceous utilization is relatively uniform and falls within the moderate range (40-60\%), temporal utilization patterns are probably not of significance from a management point of view, unless livestock performance is detrimentally affected by excessive travel (Anderson and Kothmann 1980, Hart et al. 1993). In this study distance to water was less than $1.6 \mathrm{~km}$ for 2.5 days and more than $1.6 \mathrm{~km}$ for 2.5 days. The cattle never experienced a prolonged period of long distances to water. The effect of long distances to water on livestock performance may be ameliorated by limiting the time period and offsetting it with exposures to short distances to water. Cattle in this study ranged $3.2 \mathrm{~km}$ from water (and would have probably gone further), and at the end of a 5 day grazing period, grass utilization was relatively uniform.

Visual estimates of utilization in this study were consistently 15-20\% less than clipped estimates. Visual estimates are generally considered inferior to clipped estimates because of observer bias. However, clipped estimates may also contain a considerable level of potential error or bias. In the vegetation of this study, stubble heights after grazing were less than $2-3 \mathrm{~cm}$. With short stubble, and frequently windy days, residual material can be shattered and lost before or during clipping. This causes underestimation of residual plant material and overestimation of utilization, using the before and after clipping method. Also, variation in rangeland vegetation can occur in very short distances. This can result in large errors in clipped utilization estimates simply because of large differences in standing crop between 2 adjacent clip plots.

\section{Conclusions}

Livestock utilization within intensively managed fields is not evenly distributed. Although utilization at the end of grazing periods may be uniform, temporal grazing patterns exist. Livestock 
distribution in this study was similar to that in previous work, but the size of the livestock herd was much larger. Little management-scale evaluation of utilization has been done previously on intensive management systems.

\section{Literature Cited}

Anderson, D.M. and M.M. Kothmann. 1980. Relationship of distance traveled with diet and weather for hereford heifers. J. Range Manage. 33:217-220.

Cook, C.W. 1966. Factors affecting utilization of mountain slopes by cattle. J. Range Manage. 19:200-204

Coupland, R.T. 1961. A reconsideration of grassland classification in the Northern Great Plains of North America. J. Ecology 49:135-167.

Environment Canada. 1982. Canadian Climate Normals Volume 3: Precipitation 1951-1980. Ottawa, Ontario.

Gillen, R.L., W.C. Krueger, and R.F. Miller. 1984. Cattle distribution on mountain rangeland in north-eastern Oregon. J. Range Manage. $37: 549-553$.

Hart, R.H., J. Bissio, M.J. Samuel, J.W. Waggoner Jr. 1993. Grazing systems, pasture size, and cattle grazing behaviour, distribution and gains. J. Range Manage. 4:681-87.

Irving, B.D. 1992. The effect of litter on the herbage growth cycle, soil water, and soil temperature in the Aspen Parkland of Alberta. M.Sc. Thesis, University of Alberta, Edmonton, Alberta.
Kirby, D.R., M.F. Pessin, and G.K. Clambey. 1986. Disappearance of forage under short duration and season long grazing. J. Range Manage. 39:496-499.

Kothmann, M.M. 1980. Evaluation of livestock needs on designing grazing systems for rangeland. Chap. 6 Part B. In: Digestive Physiology and Nutrition of Ruminants, D.C. Church (ed.), Vol 3. O\&B Books, Inc. Corvallis, Ore.

Looman, J. 1981. The vegetation of the Canadian Prairie Provinces II. The grasslands, Part 2 Mesic grasslands and meadows. Phytocoenologia 9:1-26.

Mueggler, W.F. 1965. Cattle distribution on steep slopes. J. Range Manage. 18:255-257.

Pavlick, L.E. and J. Looman. 1984. Taxonomy and nomenclature of rough fescues, Festuca altaica, Festuca campestris, $(F$. scabrella var. major) and Festuca hallii, in Canada and the adjacent part of the United States. Can. J. Bot. 62:1739-1749.

Roath, L.R., and W.C. Kruegger. 1982. Cattle grazing and behaviour on a forested range. J. Range Manage. 35:332-338.

Walker, J.W., R.K. Heitschmidt, and S.L. Dowhower. 1989. Some effects of a rotational grazing treatment on cattle preference for plant communities. J. Range Manage. 42:143-148.

Wyatt, F.A. and J.D. Newton. 1938. Soil survey of Sullivan Lake sheet. Univ. of Alberta, College of Agr. Bull. 31. 